\title{
Evaluasi Waktu Penyelesaian Proyek dengan Metode PERT (Project Evaluation and Review Technique) di PT.ConcoPhillips Indonesia \\ (Suban Tie In,April 1-2,2006)
}

\author{
Bulan Oktrima \\ Program Studi Matematika, FMIPA - UNPAM \\ bulanoktrima17@gmail.com
}

\begin{abstract}
ABSTRAK
PERT (Project Evaluation and Review Technique) adalah suatu tehnik statistik yang berkaitan dengan evaluasi dan prediksi jaringan kerja yang dikarenakan adanya masalah ketidakpastian di dalam pelaksanaan proyek.Tehnik ini memusatkan perhatiannya pada pengelolaan sistem jaringan tersebut,terutama pada kegiatan tertentu yang membutuhkan penanggulangan supaya pelaksanaan keseluruhannya tidak mengalami goncangan yang berarti. Tugas Akhir ini membahas metode PERT yang digunakan dalam mengevaluasi waktu yang diberikan oleh para Planner dalam penyelesaian proyek di PT.ConocoPhillips Indonesia yang berlokasi di Sumatera Selatan.Data yang diperoleh berupa kegiatan-kegiatan proyek dan lama waktu kegiatan,sehingga dapat dihitung dan diketahui kegiatan manakah yang merupakan Critical Path (jalur kritis). Evaluasi pada waktu proyek yang menggunakan metode PERT menghasilkan waktu-waktu atau perkiraan pemberian durasi kegiatan pada proyek tersebut ternyata sangat baik.
\end{abstract}

Kata Kunci : PERT,Critical Path,Probalitas keberhasilan proyek 


\section{PENDAHULUAN}

\subsection{Latar Belakang Masalah}

Kegiatan-kegiatan proyek telah dilakukan sejak dahulu.Kegiatan tersebut kadangkala meliputi pembangunan jalan umum,rumah untuk tempat tinggal,dan bahkan proyek dalam skala besar yang dewasa ini makin beraneka ragam,canggih dan kompleksitasnya sangat besar dari berbagai instansi atau perusahaan,sehingga terjadi persaingan yang semakin kuat,maka dalam pengerjaan suatu kegiatan harus benar-benar efektif. Namun, karena disebabkan oleh kurangnya pemantapan dalam penjadwalan, sehingga mengakibatkan proses kegiatan dalam proyek pada perusahaan tersebut menjadi terhambat dan berakibat kerugian pada perusahaan yang bersangkutan.

Dengan adanya metode analisis jaringan kerja ini, terbuka kesempatan untuk dapat mengawasi secara teliti kerangka kerja yang telah, sedang, dan akan dijalankan. Jadi, dari waktu permulaan sampai dengan akhir suatu perencanaan, proses kerja yang dikelola akan dapat diikuti perkembangannya, proyek lebih efisien, mudah dipantau kemajuannya serta dengan cepat dapat diketahui apabila suatu waktu terjadi ketidakberesan dalam kaitannya dengan hubungan antara berbagai kegiatan maupun waktu yang disediakan.

Selama ini PT. ConocoPhillips Indonesia menggunakan beberapa software atau program komputer dalam membantu menyelesaikan penjadwalan proyeknya. Kadangkala dalam menjadwalkan proyek dapat dikatakan memiliki beberapa kelemahan yang tanpa disadari oleh para Planner (penjadwal proyek Perusahaan). Beberapa kelemahan dalam penjadwalan proyek di perusahaan tersebut adalah kurangnya mengetahui pemberian waktu pada kegiatan penjadwalan, tidak mengetahui kegiatan penjadwalan yang harus diprioritaskan terlebih dahulu., tidak mengetahui beberapa probabilitas keberhasilan penyelesaian proyek.

Didasari oleh adanya kendala ataupun kelemahan dalam penjadwalan yang dimiliki oleh PT. ConocoPhillips Indonesia tersebut, maka penggunaan metode lain sangat diperlukan. Dalam PERT menggunakan tiga angka estimasi bagi setiap kegiatan, yaitu optimistic, pesimistik, dan paling mungkin. Menurut Sri Mulyono [2] dengan memberikan rentang waktu ini, metode PERT bermaksud menampung adanya unsurunsur yang belum pasti, kemudian menganalisis kemungkinan-kemungkinan sejauh mana proyek menyimpang atau memenuhi sasaran jadwal penyelesaian. Oleh karena itu, PERT 
banyak digunakan dalam bidang penelitian dan pengembangan, yang sering kali memiliki unsur waktu (periode) dari masing-masing kegiatan yang belum menentu.

Berdasarkan latar belakang tersebut maka dilakukan penelitian mengenai Evaluasi Waktu Penyelesaian Proyek dengan Metode PERT (Project Evaluation and Review Technique) di PT. ConocoPhillips Indonesia (Suban Tie-In,April 1-2, 2006).

\subsection{Rumusan Masalah}

Berdasarkan identifikasi dan batasan masalah yang telah diuraikan di atas, selanjutnya perumusan masalah dalam penelitian ini adalah:

1. Bagaimana waktu tercepat dan waktu terlambat suatu kegiatan proyek dalam penjadwalan?

2. Kegiatan proyek manakah yang merupakan Slack / Floating dan Critical Path dari keseluruhan kegiatan penjadwalan?

3. Berapa probabilitas keberhasilan proyek tersebut di selesaikan sesuai dengan waktu yang ditentukan?

\subsection{Tujuan Penelitian}

Dari rumusan masalah di atas maka penelitian ini bertujuan untuk :

1. Menghitung dan mengetahui waktu tercepat dan waktu terlama dalam kegiatan proyek

2. Mengetahui kegiatan proek yang merupakan Slack dan critical path

3. Mengetahui probabilitas keberhasilan proyek tersebut di selesaikan sesuai dengan rencana dan memberikan informasi mengenai kegiatan penjadawalan,perencanaan, dan pengawasan dalam proyek.

\subsection{Manfaat Penelitian}

Manfaat praktis dari penelitian ini adalah untuk mengetahui seberapa banyak jumlah penjualan produk setiap bulannya untuk beberapa lima bulan mendatang dan dapat mengurangi biaya pendistribusian produk. Manfaat teoritis dari penelitian ini adalah untuk digunakan bagi kemajuan dan pengembangan ilmu pengetahuan sebagai bahan referensi, serta untuk pengembangan penelitian tentang hal sama pada masa selanjutnya. 


\section{METODOLOGI PENELITIAN}

Data yang diperoleh dari program software Microsoft Project, dapat diamati pemberian waktu-waktu dalam penjadwalan kegiatan proyek tersebut. Dimana waktu tersebut merupakan lamanya waktu penyelesaian / pengerjaan suatu kegiatan. Sehingga dapat dihitung waktu-waktu seperti : ES, EF, LS, LF, dan slack atau float.

Rumus menghitung waktu mulai paling awal:

Rumus meghitung waktu selesai paling lambat :

Rumus menghitung penundaan waktu kegiatan :

Rata-rata $\left(\mathrm{t}_{\mathrm{i}}\right)$ dan varian $\left(\sigma_{\mathrm{i}}^{2}\right)$ seperti berikut :

$t_{\mathrm{i}}=\frac{a_{\mathrm{i}}+4 \cdot m_{\mathrm{i}}+b_{\mathrm{i}}}{6}$ dan $\quad \sigma_{\mathrm{i}}^{2}=\left(\frac{b_{\mathrm{i}}-a_{\mathrm{i}}}{6}\right)^{2}$

Untuk menghitung probabilitas proyek, dengan rumus : $\quad X=\left(\frac{X-\mu}{\sigma}\right)$

\subsection{Distribusi Normal dalam Excel}

Fasilitas fungsi dalam Excel untuk perhitungan yang berkaitan dengan aplikasi distribusi normal :

1. Penentuan probabilitas harga variable $\mathrm{X}$ dalam distribusi normal dengan mean $(\mu)$ dan deviasi standar $(\sigma)$ yang tertentu :

a. Fungsi: NORMDIST ( $\mathrm{x}, \mu, \sigma$, cumulative).

b. $\mathrm{P}(31)$ : $\operatorname{NORMDIST}(31,30,2,0)=\operatorname{NORMDIST}(31,30,2$, False $)=$ 0.1760 .

c. $\mathrm{F}(31)$ : NORMDIST $(31,30,2,1)=\operatorname{NORMDIST}(31,30,2$, True $)=$ 0.6915 .

2. Penentuan kembali (inversi) harga variable $\mathrm{X}$ bila diketahui probabilitas kumulatifnya (p) dalam distribusi normal mean $(\mu)$ dan deviasi standar $(\sigma)$ yang tertentu:

a. Fungsi: NORMINV $(\mathrm{P}, \mu, \sigma)$.

b. $\mathrm{X}(\mathrm{p}=0.6915)=\operatorname{NORMINV}(0.6915,30,2)=31$

c. $\mathrm{X}(\mathrm{p}=0.3085)=\operatorname{NORMMINV}(0.3085,30,2)=29$

\subsection{Metode Penelitian}

Metode penelitian yang digunakan pada penelitian metode evaluasi formatif yang menekankan pada proses dari hal yang akan diteliti. 


\subsection{Metode Penentuan Sampel}

Data-data yang diperlukan untuk penelitian, diperoleh dengan cara peninjauan langsung di lapangan. Dari peninjauan yang dilakukan langsung di lapangan, penulis mengadakan wawancara tanya jawab serta observasi. Kemudian data yang akan diperoleh berupa data skunder.

\subsection{Metode Pengolahan Data}

Data-data berupa proses kegiatan, waktu kegiatan, lama kegiatan (durasi), urutan kegiatannya, kegiatan-kegiatan yang digunakan dalam proyek,keterkaitan antar kegiatan yang terjadi diolah dengan menggunakan program software yaitu Microsoft Excel. Setelah data diperoleh, kemudian dipelajari, dicermati dan mencoba menghubungkan data tersebut dengan kebutuhan penelitian. Sehingga dari data yang telah diolah tersebut, maka dapat dibuat sebuah kesimpulan sehingga dapat menjawab permasalahan yang diajukan.

\section{HASIL DAN PEMBAHASAN}

\subsection{Data Penelitian}

Tabel 3.1. Data Proyek Suban Tie-In, April 1-2 2006, Sumatera Selatan

\begin{tabular}{|c|l|c|c|}
\hline NO & \multicolumn{1}{|c|}{ TASK NAME } & DUR & PREDE-CESSORS \\
\hline 1 & Shut Down SBN & $6 \mathrm{hrs}$ & $\#$ \\
\hline 2 & Blinding & $3 \mathrm{hrs}$ & 1 \\
\hline 3 & SBN - Shutdown:4 wells & $2 \mathrm{hrs}$ & $\#$ \\
\hline 4 & Isolate 16" \& 20 “ Valve on CGP & $1 \mathrm{hrs}$ & 3 \\
\hline 5 & Residu Gas Compressor & $3 \mathrm{hrs}$ & $\#$ \\
\hline 6 & Depressurize to 550 Psi & $4 \mathrm{hrs}$ & 4, dummy \\
\hline 7 & Depressurize to 0 Psi & $9 \mathrm{hrs}$ & 6 \\
\hline 8 & Install Temp Vent Line & $3 \mathrm{hrs}$ & 6 \\
\hline 9 & Depressurize Air Header - Isolation & $3 \mathrm{hrs}$ & 2 \\
\hline 10 & Tie In Job \#04 & $8 \mathrm{hrs}$ & $7, \mathrm{dummy}$ \\
\hline 11 & Tie In job \#05 (ti-72, 77 ,96, 97) & $8 \mathrm{hrs}$ & 9 \\
\hline 12 & $\begin{array}{l}\text { Tie In Job \#06 (TI-12, 36, 66, 67, 99, } \\
82, \text { Turn 3" valve (2ea) }\end{array}$ & $12 \mathrm{hrs}$ & 9 \\
\hline 13 & Internal Inspection Glycol Flash Drums & $12 \mathrm{hrs}$ & 9 \\
\hline 14 & Start Up Instrument Air Header & $4 \mathrm{hrs}$ & 11 \\
\hline
\end{tabular}




\begin{tabular}{|c|l|c|c|}
\hline 15 & De-Blinding & 4 hrs & 10,12 ,dummy \\
\hline 16 & Start Up SBN & $6 \mathrm{hrs}$ & 15, dummy \\
\hline 17 & Purging \& Leak Check & $4 \mathrm{hrs}$ & 15 ,dummy \\
\hline 18 & Repack Trunkline & $8 \mathrm{hrs}$ & 16 \\
\hline 19 & Shutdown BNTY & $4 \mathrm{hrs}$ & $\#$ \\
\hline 20 & Depressurize 4" Fuel Line & $3 \mathrm{hrs}$ & 20 \\
\hline 21 & Tie In 4” Fuel Line & $4 \mathrm{hrs}$ & 21 \\
\hline 22 & Purging \& Pressurize & $4 \mathrm{hrs}$ & 22 \\
\hline 23 & Start Up BNTY & $3 \mathrm{hrs}$ & 23 \\
\hline 24 & Normal Operation & $3 \mathrm{hrs}$ & 24 \\
\hline
\end{tabular}

Keterangan :

Dari banyaknya kegiatan proyek yang telah dilakukan, dalam jaringan hanya ditampilkan 25 kegiatan yang telah mewakili banyaknya kegaitan-kegiatan yang dilakukan dalam proyek tersebut.
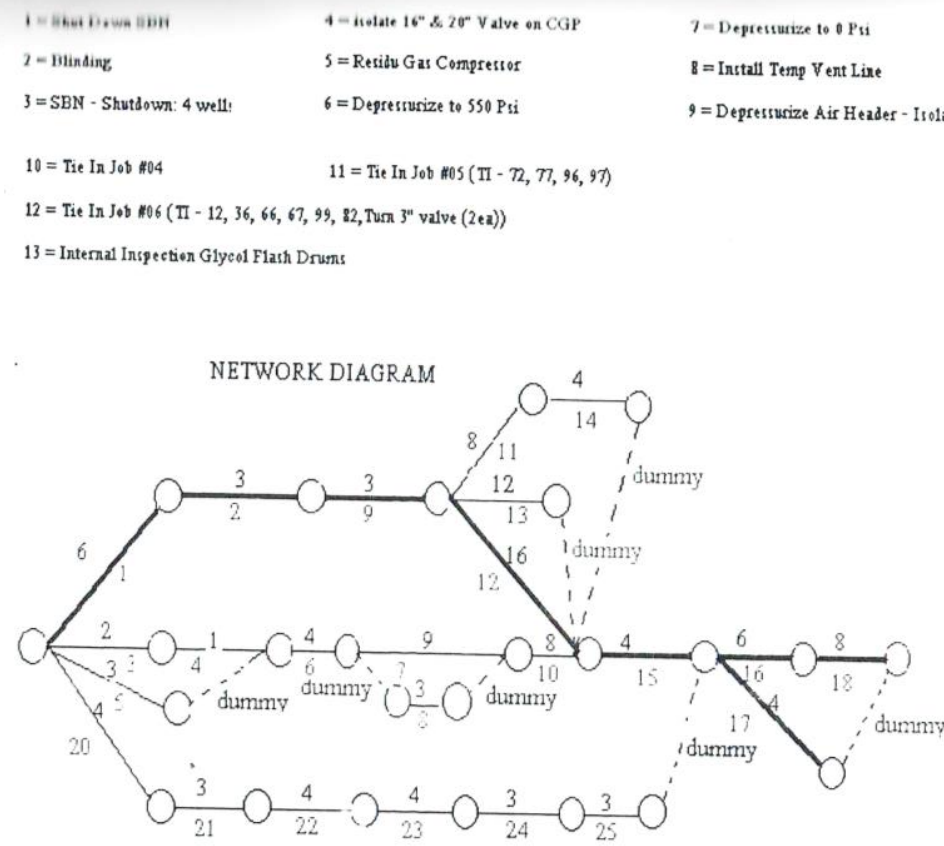

SUBAN - BENTAYAN SHUTDOWN SEQUENCE

SUBAN TIE - IN, APRIL 1 - 2, 2006

Diagram 12. Perancangan Jaringan Kerja Proyek

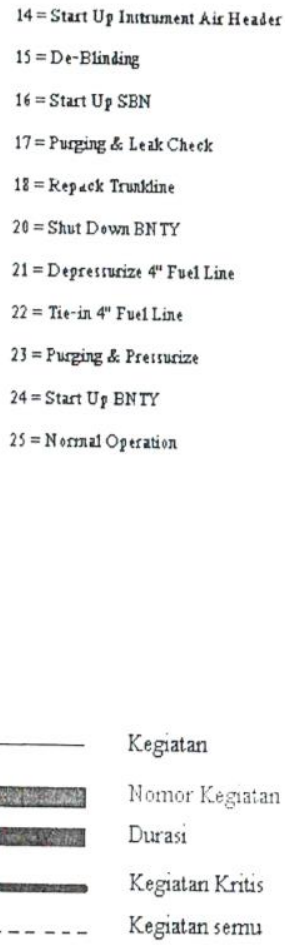




\subsection{Perhitungan Expected Time dan Variance}

Tabel 3.2. Perhitungan Slack dan Critical Path

\begin{tabular}{|c|c|c|c|c|c|c|c|}
\hline NO & TASK NAME & ES & EF & $\mathbf{L S}$ & LF & $\mathbf{S}$ & $\mathbf{C P}$ \\
\hline 1 & Shut Down SBN & 0 & 6 & 0 & 6 & 0 & YES \\
\hline 2 & Blinding & 6 & 9 & 6 & 9 & 0 & YES \\
\hline 3 & SBN - Shutdown: 4 wells & 0 & 2 & 4 & 6 & 4 & \\
\hline 4 & Isolate $16 " \& 20 "$ Valve on CGP & 2 & 3 & 6 & 7 & 4 & \\
\hline 5 & Residu Gas Compressor & 0 & 3 & 4 & 7 & 4 & \\
\hline 6 & Depressurize to $550 \mathrm{Psi}$ & 3 & 7 & 7 & 11 & 4 & \\
\hline 7 & Depressurize to 0 Psi & 7 & 16 & 11 & 20 & 4 & \\
\hline 8 & Install Temp Vent Line & 7 & 16 & 11 & 20 & 4 & \\
\hline 9 & Depressurize Air Header - Isolation & 9 & 12 & 9 & 12 & 0 & YES \\
\hline 10 & Tie In Job \#04 & 16 & 24 & 20 & 28 & 4 & \\
\hline 11 & Tie In job \#05 (ti-72, $77,96,97)$ & 12 & 20 & 16 & 24 & 4 & \\
\hline 12 & $\begin{array}{l}\text { Tie In Job \#06 (TI-12, 36, 66, 67, 99, 82, } \\
\text { Turn 3" valve (2ea) }\end{array}$ & 12 & 28 & 12 & 28 & 0 & YES \\
\hline 13 & Internal Inspection Glycol Flash Drums & 12 & 24 & 16 & 28 & 4 & \\
\hline 14 & Start Up Instrument Air Header & 20 & 24 & 24 & 28 & 4 & \\
\hline 15 & De-Blinding & 28 & 32 & 28 & 32 & 0 & YES \\
\hline 16 & Start Up SBN & 32 & 38 & 32 & 38 & 0 & YES \\
\hline 17 & Purging \& Leak Check & 32 & 36 & 32 & 36 & 0 & YES \\
\hline 18 & Repack Trunkline & 38 & 46 & 38 & 46 & 0 & YES \\
\hline 19 & Shutdown BNTY & 0 & 4 & 11 & 15 & 11 & \\
\hline 20 & Depressurize 4" Fuel Line & 4 & 7 & 15 & 18 & 11 & \\
\hline 21 & Tie In 4" Fuel Line & 7 & 11 & 18 & 22 & 11 & \\
\hline 22 & Purging \& Pressurize & 11 & 15 & 22 & 26 & 11 & \\
\hline 23 & Start Up BNTY & 15 & 18 & 26 & 29 & 11 & \\
\hline 24 & Normal Operation & 18 & 21 & 29 & 32 & 11 & \\
\hline
\end{tabular}


Tabel 3.3. Perhitungan Slack dan Critical Path

\begin{tabular}{|c|c|c|c|c|c|c|}
\hline NO & $\begin{array}{r}\text { TASK NAME } \\
\end{array}$ & (a) & (m) & (b) & $\left(\mathbf{t}_{\mathbf{i}}\right)$ & $\left(\sigma_{i}^{2}\right)$ \\
\hline 1 & Shut Down SBN & 5.5 & 6 & 6 & 5.916666667 & 0.006944444 \\
\hline 2 & Blinding & 3 & 3 & 3.5 & 3.083333333 & 0.006944444 \\
\hline 3 & SBN - Shutdown: 4 wells & 2 & 2.5 & 2.5 & 2.416666667 & 0.006944444 \\
\hline 4 & Isolate $16 " \& 20 "$ Valve on CGP & 1 & 1 & 1.5 & 1.083333333 & 0.006944444 \\
\hline 5 & Residu Gas Compressor & 3 & 3 & 3.5 & 3.083333333 & 0.006944444 \\
\hline 6 & Depressurize to 550 Psi & 4 & 4 & 4.5 & 4.083333333 & 0.006944444 \\
\hline 7 & Depressurize to $0 \mathrm{Psi}$ & 8 & 9 & 10 & 9 & 0.111111111 \\
\hline 8 & Install Temp Vent Line & 3 & 3 & 3.5 & 3.083333333 & 0.006944444 \\
\hline 9 & Depressurize Air Header - Isolation & 2.5 & 3 & 3 & 2.916666667 & 0.006944444 \\
\hline 10 & Tie In Job \#04 & 7 & 8 & 9 & 8 & 0.111111111 \\
\hline 11 & Tie In job \#05 (ti-72, $77,96,97)$ & 7 & 8 & 9 & 8 & 0.111111111 \\
\hline 12 & $\begin{array}{l}\text { Tie In Job \#06 (TI-12, 36, 66, 67, 99, 82, } \\
\text { Turn 3" valve (2ea) }\end{array}$ & 11.5 & 12 & 12 & 11.91666667 & 0.006944444 \\
\hline 13 & Internal Inspection Glycol Flash Drums & 11.5 & 12 & 12 & 11.91666667 & 0.006944444 \\
\hline 14 & Start Up Instrument Air Header & 4 & 4 & 4.5 & 4.083333333 & 0.006944444 \\
\hline 15 & De-Blinding & 4 & 4 & 4.5 & 4.083333333 & 0.006944444 \\
\hline 16 & Start Up SBN & 6 & 6 & 6.5 & 6.083333333 & 0.006944444 \\
\hline 17 & Purging \& Leak Check & 4 & 4 & 4.5 & 4.083333333 & 0.006944444 \\
\hline 18 & Repack Trunkline & 7.5 & 8 & 8 & 7.916666667 & 0.006944444 \\
\hline 19 & Shutdown BNTY & 4 & 4 & 4.5 & 4.083333333 & 0.006944444 \\
\hline 20 & Depressurize 4" Fuel Line & 3 & 3 & 3.5 & 3.083333333 & 0.006944444 \\
\hline 21 & Tie In 4" Fuel Line & 3 & 4 & 4.5 & 3.916666667 & 0.0625 \\
\hline 22 & Purging \& Pressurize & 3 & 4 & 4.5 & 3.916666667 & 0.0625 \\
\hline 23 & Start Up BNTY & 3 & 3 & 3.5 & 3.083333333 & 0.006944444 \\
\hline 24 & Normal Operation & 3 & 3 & 3.5 & 3.083333333 & 0.006944444 \\
\hline & Total & 40 & 42 & 48 & 121.9166667 & 0.590277778 \\
\hline
\end{tabular}

Data pada table 3.2, selanjutnya dilakukan perhitungan expected time dan

variance pada table 3.3 Dengan menggunakan rumus:

$$
\begin{gathered}
t_{\mathrm{i}}=\frac{a_{\mathrm{i}}+4 . m_{\mathrm{i}}+b_{\mathrm{i}}}{6} \\
\sigma^{2}{ }_{\mathrm{i}}=\left(\frac{b_{\mathrm{i}}-a_{\mathrm{i}}}{6}\right)^{2}
\end{gathered}
$$

Perhitungan penyimpangan standar,digunakan untuk menghitung probabilitas selesainya proyek menggunakan distribusi normal sesuai dengan waktu yang diharapkan. Waktu penyelesaian proyek tergantung dari waktu (durasi) yang diambil dari kegiatan kritis, yaitu : Kegiatan 1, 2, 9, 12, 15, 16, 17 dan 18 seperti dalam perhitungan critical path pada table 2 .

Penyimpangan standar jalur kritis adalah : 


$$
\begin{gathered}
\sigma=\sqrt{\sigma_{1}^{2}+\sigma_{2}^{2}+\sigma_{9}^{2}+\sigma_{12}^{2}+\sigma_{15}^{2}+\sigma_{16}^{2}+\sigma_{17}^{2}+\sigma_{18}^{2}} \\
\sigma=\sqrt{(0,00694)+(0,00694)+(0,00694)+(0,00694)+(0,00694)+(0,00694)+(0,00694)+(0,00694)} \\
\sigma=\sqrt{0,05556}
\end{gathered}
$$

$\sigma=0,2357$

dan waktu jalur kritis selesainya proyek dihitung sebagai berikut:

$$
\begin{gathered}
\mu=t_{1}+t_{2}+t_{9}+t_{12}+t_{15}+t_{16}+t_{17}+t_{18} \\
\mu=(5,9167)+(3,0833)+(2,9167)+(11,9167)+(4,0833)+(6,0833)+(4,0833)+(7,9167) \\
\mu=46 \mathrm{Jam}
\end{gathered}
$$

Dengan nilai $\sigma$ dan $\mu$, probabilitas proyek dengan lamanya waktu yang diharapkan dapat dihitung dengan menggunakan rumus sebagai berikut :

$$
Z h=\frac{(X-\mu)}{\sigma}
$$

Dimana :

$$
\begin{aligned}
& X=\text { Waktu diharapkan selesainya proyek } \\
& \mu=\text { Waktu jalur kritis selesainya proyek } \\
& \sigma=\text { Penyimpangan standar jalur kritis }
\end{aligned}
$$

Sehingga dengan diketahui bahwa $X=48$ jam, maka :

$$
Z h=\frac{48-46}{0,2357}=8,485
$$

Dengan menggunakan Microsoft Excel atau dengan table distribusi normal (lampiran 1), dapat diketahui berapa persentase keberhasilan proyek tersebut.

Dengan nilai yang telah diperoleh $\mathrm{Zh}=8,485$ dengan $\mathrm{X}$ selama 48 jam,dapat diperoleh bahwa keberhasilan proyek ini adalah 100\%.

\section{SIMPULAN DAN SARAN}

Simpulan penelitian ini yaitu:

Dari hasil perhitungan,waktu terawal dan waktu selambat-lambatnya telah dapat diketahui nilainya.Pada awal kegiatan atau pada kegiatan 1, nilai ES1 $=0$ (nol), ini logis sebab belum ada kegiatan sebelumnya,sehingga dapat dikatakan sebagai waktu mulai tercepat dari kegiatan proyek. Jika dibandingkan dengan ES 
$=38$,ini dikarenakan telah ada kegiatan terdahulunya. Selain itu,terdapat juga nilai LS yaitu waktu mulai terlambat. Jika masing-masing kegiatan tersebut dapat ditunda sebesar nilai yang terhitung. Namun apabila nilainya sama dan hasil perhitungan slack nilainya adalah nol, maka kegiatan tersebut dikatakan kegiatan kritis.

Sehingga dari kegiatan proyek Suban Tie-In, terdapat 8 kegiatan yang kritis yang disebut dengan critical path (jalur kritis). Dan kegiatan tersebut harus benarbenar diperhatikan karena apabila terjadi penundaan waktu, maka akan mempengaruhi waktu penyelesaian proyek.

Ternyata waktu yang dirancang untuk penjadwalan proyek oleh planner perusahaan adalah sangat baik dan efektif. Karena perhitungan yang dilakukan oleh metode PERT, menghasilkan waktu yang diharapkan tersebut probabilitasnya tingkat keberhasilannya adalah sebesar 100\%. Dengan waktu yang diharapkan dalam penyelesaian proyek adalah selama 48 jam, yang merupakan waktu efisiensi. Namun, dalam ilmu statistic nilai $100 \%$ tersebut sangat tidak mungkin, sehingga alasan kenapa tingkat probabilitas keberhasilan proyek tersebut $100 \%$ adalah karena waktu yang diharapkan dan waktu-waktu kegiatan yang digunakan dalam penyelesaian proyek tersebut,merupakan waktu hasil perbaikan, dimana kegiatan proyek ini telah berlangsung dan dilakukan peninjauan ulang penggunaan waktu untuk masing-masing kegiatan oleh planner tersebut.

\section{DAFTAR PUSTAKA}

D. B. Nasendi. Mengenal Analisa Rangkaian dan Pengendalian Pelaksanaan Proyek dengan Model PERT / CPM. 34(2): 37-47. Majalah Insinyur Indonesia.1986

Mulyono, Sri.Riset Operasi, Lembaga Penerbit Fakultas Ekonomi UI.Jakarta.2003

Sabari, Hadi.Perancangan Network. Cetakan Pertama. PT. Hardana Ekacitra Tunggal. Yogyakarta. 1991.

Soeharto, Iman. Manajemen Proyek Dari Konseptual Sampai Operasional. Penerbit Erlangga. Jakarta. 1995.

Soeparlan, Soetoyo. Teknik Penjadwalan dengan Menggunankan Metode PERT. 10(4):40-44. Majalah Matematika dan Komputer

Syafriandi. Aplikasi Microsoft Project 2000 Untuk Penjadwalan Kerja Dalam Proyek Teknik Sipil. PT. Dinastindo Adiperkasa Internasional .Jakarta .2003

Wahana Komputer, Tim Penelitian Dan Pengembangan. Pengelolaan Proyek Dengan Microsoft Project 2003. Edisi Pertama. Salemba Infotek.Jakarta .2005 